\title{
Analisis Keberlanjutan Agribisnis Paprika di Bandung Barat
}

\section{Analysis of Paprika Agribusiness Sustainability in Bandung Barat}

\section{Aji Nursidiq*, Trisna Insan Noor, dan Lucyana Trimo}

${ }^{1}$ Fakultas Pertanian Universitas Padjadjaran

*E-mail: ajinursidiq91@gmail.com

\begin{abstract}
West Bandung Regency is an area of paprika production centers. The decline in quality and quantity of production, dependence on imported seeds and the difficulty of access to financial institutions can have implications for the sustainability of paprika agribusiness. The purpose of this study was to analyze the performance of paprika agribusiness sustainability in Bandung Barat. Based on census sampling, this study uses questionnaires and discussions with relevant parties in data collection. The economic, social, environmental, technological and institutional dimensions were analyzed using an average index of farmers' perceptions. The results show that the sustainability performance of paprika agribusiness in Bandung Barat is sufficient with the highest social dimension and the lowest technological dimension. This sustainability performance can be improved by improving every dimension. Therefore, in policy planning for the development of the paprika agribusiness sustainability, it is best to prioritize the improvement of indicators that have a large effect on their dimensions.
\end{abstract}

Keywords: agribusiness, agribusiness sustainability, paprika

Disubmit: 28 Agustus 2019; Diterima: 10 Oktober 2019; Disetujui: 28 November 2019

\section{PENDAHULUAN}

Bertambahnya warga negara asing, turis dan adanya perubahan gaya hidup serta pola konsumsi masyarakat perkotaan berupa menu sayuran (khususnya Asian food dan Western food) yang semakin populer, membuat paprika menjadi produk sayuran yang berpotensi untuk berkembang di Indonesia. Permintaan semakin meningkat dan didukung tersedianya lahan dataran tinggi yang cukup banyak di Indonesia. Selain itu, paprika sudah dikenal di Indonesia bahkan pasar lokal dapat menyerap produksi paprika dari berbagai daerah produksi. Perkembangan tersebut dapat berdampak terhadap pencapaian pasar ekspor (Gunadi et al., 2007).

Kabupaten Bandung Barat merupakan penyumbang paprika terbesar untuk produksi paprika di Indonesia. Berdasarkan data KEMENTAN (2015), produksi paprika di Kabupaten Bandung Barat hingga tahun 2014 menyumbang sekitar 57,64\% dari total produksi Indonesia. Walaupun sekarang bermunculan wilayah produksi paprika seperti di Jawa Timur, Jawa Tengah, Sumatra, Bali, dan Nusa Tenggara Barat, tetapi Jawa Barat masih menjadi sentra produksi yang menyumbang sekitar $61,62 \%$ dari total produksi di Indonesia (BPS, 2019).

Paprika merupakan komoditas sayuran yang bernilai jual tinggi dan telah menembus pasar internasional. Salah satu negara yang menjadi tujuan ekspor paprika Indonesia adalah Taiwan. Namun sejak sekitar tahun 2003 sampai 2004, ekspor paprika ke Taiwan terhenti akibat adanya isu lalat buah. Walaupun demikian, Taiwan bukanlah satu-satunya negara tujuan ekspor paprika Indonesia. Negara lain yang juga menjadi tujuan ekspor paprika Indonesia adalah Hongkong dan Singapura.

Pendugaan agribisnis paprika yang tidak berkelanjutan dilihat dari beberapa permasalahan yang terjadi salah satunya yaitu terjadi pemberhentian ekpor paprika tahun 2014 terhenti karena penurunan kualitas dan kuantitas produksi paprika yang dihasilkan Indonesia padahal potensi pasar internasional masih terbuka lebar 
untuk produk paprika di Indonesia (Al Hafiz MP, 2016). Selain itu permasalahan yang terjadi pada paprika yaitu ketersediaan benih karena masih bergantung benih impor, kemudian akses terhadap lembaga keuangan yang sulit dijangkau petani skala kecil. Permasalahan tersebut termasuk kedalam sistem agribisnis dimana menurut hasil penelitian Ristianingrum et al. (2016), bahwa faktor yang menjadi permasalahan terhambatnya keberlanjutan agribisnis yaitu sumberdaya manusia yang merupakan subsistem budidaya, kelembagaan dari subsistem penunjang serta pasar produk dari subsistem pemasaran.

Usaha peningkatan produksi paprika melalui pendekatan agribisnis bertumpu pada pemberdayaan petani agar mampu berusaha tani secara kelompok, membentukbadan usaha yang berorientasi profit serta mengadopsi teknologi produksi yang bercirikan efisiensi tinggi dan produk yang kompetitif. Konsep tersebut merupakan salah satu aksi dibidang pertanian dari konsep pembangunan berkelanjutan berlandaskan tiga pilar ekonomi, sosial dan ekologi (lingkungan) yang dipopulerkan melalui laporan WCED (World Commission on Environmental and Development) tahun 1987 (Munashinge, 1993). Selain ketiga pilar dimensi tersebut beberapa peneliti melakukan analisis terhadap lima pilar dengan dua pilar tambahan yaitu dimensi teknologi dan dimensi kelembagaan ((Novita et al., 2012); Ristianingrum et al., 2016). Melalui pilar tersebut diharapkan keberlanjutan agribisnis paprika terbentuk tidak hanya dari produksi saja tetapi dapat dilihat dari segi ekonomi, lingkunganm sosial, teknologi dan kelembagaan.

Berdasarkan permasalahan tersebut, tujuan penelitian ini adalah untuk mengetahui tingkat keberlanjutan agribisnis paprika di Kabupaten Bandung Barat sehingga diharapkan dapat diketahui faktor-faktor yangmemengaruhi dan alternatif kebijakan yang tepat untuk keberlanjutan agribisnis paprika.

\section{METODE PENELITIAN}

Penelitian dilakukan selama 6 bulan sejak bulan Februari hingga Juli 2019 di Desa Pasirlangu Kecamatan Cisarua Kabupaten Bandung Barat. Pemilihan lokasi penelitian ditentukansecara sengaja (purposive) dengan pertimbangan bahwa Desa Pasirlangu Kecamatan Cisarua Kabupaten Bandung Barat sentra produksi paprika yang telah melakukan budidaya lebih dari 20 tahun, serta wilayah tersebut memiliki organisasi berbentuk koperasi dan kelompok tani.

Metode penelitian yang digunakan adalah metode survey dengan menggunakan kuesioner sebagai alat pengumpulan data. Pengisian kuesioner dilakukan terhadap seluruh sampel yang tersedia (metode sesnsus) di wilayah penelitian yaitu sebanyak 127 petani, serta para pengurus kelompok tani maupun koperasi dari instansi terkait yang dipilih secara sengaja (purposive). Teknik pengumpulan data dilakukan dengan cara observasi langsung, wawancara terstruktur, wawancara terarah dan teknik pencatatan. Jenis data yang dikumpulkan berupa data primer dan sekunder. Data primer diperoleh dari hasil pengamatan di lapangan dan para stakeholder yang menjadi sasaran evaluasi keberlanjutan. Data sekunder diperoleh dari studi literatur dan referensi yang relevan dengan kebutuhan. Penentuan metode sensus dilakuakn terkait dengan syarata minimal sampel penelitian yang dinyatakan oleh Guadagnoli E. dan Velicer W.F (1988) ada syarat minimum sampel yang direkomendasikan yaitu 100-200.

Konsep pembangunan berkelanjutan bersifat multi disiplin karena banyak dimensi pembangunan yang harus dipertimbangkan, antara lain dimensi ekonomi, sosial, lingkungan, teknologi dan kelembagaan. Indikator merupakan salah satu cara untuk melakukan penilaian dan mempromosikan keberlanjutan suatu usaha produksi. Indikator juga merupakan variabel bernilai yang mengindikasikan tingkat pelaksanaan dimensi.

Setiap indikator yang ditentukan harus didukung dengan kriteria sebagai penentu apakah kinerja yang dihasilkan baik atau tidak baik, maka akan sama seperti penentuan skala petani yaitu digunakan kriteria garis kontinum, yang membagi tanggapan responden menjadi 5 kategori (Sangat baik, Baik, Cukup, Tidak baik dan Sangat tidak baik). Pengkategorian dilakukan berdasarkan nilai rata-rata jawaban responden dengan cara sebagai berikut (Simamora, 2005): 


$\begin{array}{ll}\text { Skor minimum tanggapan per item } & =1 \\ \text { Skor maksimum tanggapan per item } & =5 \\ \text { Rentang (R) } & =\text { Maksimum }- \text { Minimum } \\ & =5-1=4 \\ & =5(\text { Sangat Baik, Baik, Cukup Baik, } \\ \text { Banyak Kategori (k) } & \text { Kurang Baik dan Tidak Baik) } \\ & =\mathrm{R} / \mathrm{k} \\ \text { Panjang interval } & =4 / 5=0,80\end{array}$

Maka diperoleh interval kategori sebagai berikut :
$1,00-1,80$
$=$ Tidak Baik
$1,81-2,60$
= Kurang Baik
$2,61-3,40$
$=$ Cukup Baik
$3,41-4,20$
$=$ Baik
$4,21-5,00$
$=$ Sangat baik

Lima dimensi keberlanjutan agrobisnis paprika sebagai pengembangan dari tiga dimensi keberlanjutan Munashinge (1993) yaitu ekonomi, sosial, lingkungan, teknologi dan kelembagan. Data-data primer dan sekunder diidentifikasi menjadi 14 indikator keberlanjutan yang terdiriatas 3 indikator dimensi ekonomi, 3 indikator dimensi sosial, 3 indikator dimensi lingkungan, 3 indikator dimensi teknologi dan 2 indikator dimensi kelembagaan.

\section{HASIL DAN PEMBAHASAN}

Kinerja Keberlanjutan Dimensi Ekonomi. Tujuan utama usahatani paprika adalah untuk memperoleh keuntungan, maka dari itu keberlanjutan dilihat dari dimensi ekonomi. Kinerja keberlanjutan dimensi ekonomi yang dibahas terdiri dari harga, $\mathrm{RC}$ ratio dan pendapatan. Nilai indeks rata-rata dimensi ekonomi secara umum selengkapnya dapat dilihat pada (Tabel 1). Secara umum kinerja keberlanjutan dimensi ekonomi memperoleh kategori cukup.

Petani menyetujui bahwa pedagang menentukan harga serta ada juga dimana kesepakatan harga terjadi antara petani dan pedangan yang sudah bermitra. Rata-rata petani kecil menjual produk lepas ke pedagang sehingga harga ditentukan oleh pedagang sedangkan petani besar biasanya sudah bermitra dan menentukan harga kontrak dengan jangka waktu enam bulan sampai satu tahun sehingga risiko fluktuasi harga dapat dikurangi. Perolehan indeks rata-rata pada penentuan harga dari petani tidak baik karena kebanyakan petani di wilayah sentra termasuk petani skala kecil. Hasil penelitian Paramitha \& Sulomo (2018) bahwa posisi tawar petani dengan skala lahan usaha besar lebih tinggi dibanding petani skala usaha kecil sehingga petani skala usaha besar dapat melakukan negosiasi dalam menentukan harga jual.

Kinerja RC ratio yang dihasilkan disebabkan karena petani yang menghasilkan nilai RC ratio sangat besar hanya diperoleh petani dengan skala usaha besar. Hal tersebut menunjukan kurangnya efisiensi usahatani paprika yang dilakukan petani skala kecil. Efisiensi usahatani berkaitan dengan penggunaan input produksi serta jumlah tanaman yang diusahakan (Daniel, 2004).

Kinerja keberlanjutan dimensi ekonomi dilihat dari pendapatan memperoleh hasil baik dan tertinggi, Petani memahami dengan baik jika ada keselarasan dari sistem agribisnis dapat meningkatkan pendapatan, selain itu komitmen kerjasama dengan mitra pemasaran juga dapat meningkatakan pendapatan petani. Petani mengetahui bahwa permintaan paprika cenderung meningkat yang akan berdampak terhadap pendapatan petani. Menurut Anoviansyah et al., (2018) peningkatan permintaan berpengaruh signifikan terhadap peningkatan pendapatan petani. Indikator selanjutnya yaitu ketepatan dalam penentuan pasar, karena petani paprika dapat memilih pasar yang mereka tentukan seperti menjual ke kelompok tani, pengumpul atau langsung menjual ke pasar tradisional. Kebutuhan pasar masing-masing petani berbeda, oleh karena itu ketepatan dalam menentukan pasar dapat memengaruhi pendapatan petani. 
Tabel 1 Kinerja keberlanjutan dimensi ekonomi agribisnis paprika di Kabupaten Bandung Barat

\begin{tabular}{|c|c|c|}
\hline Indikator & Indeks Rata-rata & Kinerja \\
\hline \multicolumn{3}{|l|}{ 1. Harga } \\
\hline Harga paprika sesuai dengan harapan petani & 2.65 & Cukup \\
\hline Harga paprika ditentukan oleh petani & 1.88 & Tidak Baik \\
\hline Harga ditentukan oleh pedagang & 3.66 & Baik \\
\hline Harga ditentukan oleh kesepakatan petani dan pedagang & 3.13 & Cukup \\
\hline Kinerja keberlanjutan ekonomi (harga) & 2.83 & Cukup \\
\hline 2. $\mathrm{R} / \mathrm{C}$ & 2.73 & Cukup \\
\hline \multicolumn{3}{|l|}{ 3. Pendapatan } \\
\hline $\begin{array}{l}\text { Pendapatan petani paprika akan lebih stabil jika ada keselarasan } \\
\text { dari penyediaan input hingga pemasaran. }\end{array}$ & 3.61 & Baik \\
\hline Ketepatan penentuan pasar mempengaruhi pendapatan petani & 3.58 & Baik \\
\hline $\begin{array}{l}\text { Permintaan paprika cenderung meningkat setiap tahunnya } \\
\text { sehingga meningkatkan pendapatan petani }\end{array}$ & 3.54 & Baik \\
\hline $\begin{array}{l}\text { Komitmen dengan mitra dalam kerjasama mempengaruhi } \\
\text { pendapatan petani }\end{array}$ & 3.48 & Baik \\
\hline Kinerja keberlanjutan ekonomi (pendapatan) & 3.55 & Baik \\
\hline Total skor kinerja keberlanjutan dimensi ekonomi & 2.98 & Cukup \\
\hline
\end{tabular}

Kinerja Keberlanjutan Dimensi Sosial. Kinerja keberlanjutan dimensi sosial yang dibahas terdiri dari pemberdayaan petani, dinamika kelompok dan regenerasi petani. Secara umum total skor kinerja keberlanjutan dimensi sosial berdasarkan perolehan indeks rata-rata pada agribisnis paprika di Kabupaten Bandung Barat memperoleh tingkatan kinerja cukup (Tabel 2).

Kinerja keberlanjutan agribisnis paprika berdasarkan dimensi sosial terkait dengan pemberdayaan petani memperoleh kinerja yang baik dan merupakan indeks rata-rata tertinggi. Petani sangat menyadari bahwa dengan mengikuti kegiatan pemberdayaan dapat meningkatkan kinerja agribisnis paprika. Pemberdayaan petani paprika dilakukan dengan adanya pelatihan/penyuluhan mengenai budidaya paprika yang bertujuan untuk meningkatkan kinerja usahatani. Menurut hasil penelitian Novita et al., (2012) menunjukan bahwa frekuensi penyuluhan berkontribusi besar dalam keberlanjutan dimensi sosial dalam hal ini pemberdayaan petani.

Kinerja keberlanjutan dimensi sosial yang berkaitan dengan dinamika kelompok memperoleh kategori cukup. Dinamika kelompok dalam hal ini berupa kelompok tani paprika yang sangat mempengaruhi kinerja agribisnis paprika. Kelompok tani ini berperan dalam penyediaan input produksi serta jaminan pasar yang akan meningkatkan kinerja agribisnis paprika. Selain itu keterbukaan informasi kelompok tani memberikan pengaruh terhadap kinerja dinamika kelompok. Menurut Nuryanti \& Dewa (2011) dengan bergabung pada kelompok tani, petani mendapatkan keuntungan seperti penetapan pola tanam dan mendapatkan informasi tentang teknologi yang sedang berkembang. 
Tabel 2 Kinerja keberlanjutan dimensi sosial agribisnis paprika di Kabupaten Bandung Barat

\begin{tabular}{lcc}
\hline Indikator & $\begin{array}{c}\text { Indeks Rata- } \\
\text { rata }\end{array}$ & Kinerja \\
\hline $\begin{array}{l}\text { 1. Pemberdayaan petani } \\
\text { Pemberdayaan petani akan meningkatkan kinerja usahatani paprika, }\end{array}$ & 3.28 & Cukup \\
$\begin{array}{l}\text { peningkatan kesejahteraan } \\
\text { Sangat sering (lebih dari 5 kali) dilakukan aktivitas untuk memberdayakan } \\
\text { petani paprika }\end{array}$ & 2.94 & Cukup \\
$\begin{array}{l}\text { Adanya pendampingan budidaya paprika pada saat awal pengembangan } \\
\text { Adanya kerjasama antar petani paprika }\end{array}$ & 3.65 & Baik \\
$\begin{array}{l}\text { Kinerja pemberdayaan petani } \\
\text { 2. Dinamika kelompok }\end{array}$ & 3.61 & Baik \\
$\begin{array}{l}\text { Berkomunikasi dalam kelompok adalah cara yang paling baik untuk } \\
\text { meningkatkan kinerja usahatani paprika }\end{array}$ & 3.37 & Baik \\
$\begin{array}{l}\text { Berpartisipasi dalam kegiatan gotong royong dalam membangun sarana dan } \\
\text { prasarana umum untuk mendukung kegiatan usahatani. }\end{array}$ & 2.96 & Cukup \\
$\begin{array}{l}\text { Saya menerapkan pola tanam yang sudah disepakati petani dan kelompok } \\
\text { tani }\end{array}$ & 2.65 & Cukup \\
$\begin{array}{l}\text { Kelompok tani transparan dalam informasi yang berkaitan dengan usahatani } \\
\text { Kinerja dinamika kelompok }\end{array}$ & 3.74 & Baik \\
3. Regenerasi petani & 3.24 & Cukup \\
$\begin{array}{l}\text { Dukungan keluarga akan menigkatkan regenerasi petani paprika } \\
\text { Seluruh anggota keluarga mendukung untuk berusahatani paprika }\end{array}$ & & \\
$\begin{array}{l}\text { Adanya dukungan modal dari keluarga } \\
\text { Adanya (amanat) atau tuntutan keluarga untuk Bertani paprika }\end{array}$ & 3.11 & Cukup \\
Regenerasi petani & 3.31 & Cukup \\
\hline Total skor kinerja keberlanjutan dimensi sosial & 3.15 & Cukup \\
\hline
\end{tabular}

Kinerja regenerasi petani dilihat dari adanya dukungan keluarga, dukungan permodalan serta adanya amanat untuk meneruskan sebagai indikator penentu. Indeks rata-rata tertinggi diperoleh dari dukungan anggota keluarga karena menurut petani paprika yang masih baru dalam melakukan budidaya paprika, mereka melakukan usahatani paprika karena adanya dukungan dari keluarga. Sebagian besar petani yang baru sekitar dua sampai 5 tahun melakukan usahatani paprika karena adanya dukungan dari keluarga serta dukungan permodalan untuk meneruskan usahatani paprika yang sebelumnya dilakukan oleh orang tuanya. Selain itu beberapa petani menerima amanat dan tuntutan keluarga untuk melanjutkan usahatani paprika yang telah orang tua mereka rintis. Secara umum regenerasi petani paprika di Kabupaten Bandung Barat termasuk kategori cukup. Hal tersebut sejalan dengan hasil penelitian Ristianingrum et al., (2016) dan Hosseini et al., (2011) menunjukan bahwa pemberdayaan petani, dinamika kelompok dan regenerasi petani berpengaruh signifikan terhadap keberlanjutan agribisnis dilihat dari dimensi sosial.

Kinerja Keberlanjutan Dimensi Lingkungan. Kinerja keberlanjutan berdasarkan dimensi lingkungan khususnya terkait dengan kesadaran petani tentang lingkungan diperoleh kinerja cukup. Hal ini ditunjang dengan pemahaman petani bahwa unsur lingkungan adalah faktor yang harus dipertimbangkan dalam usahatani paprika tetapi tidak sedikit juga petani yang kurang peduli terhadap lingkungan. (Tabel 3).

Secara umum petani memiliki pengetahuan dan kesadaran terhadap lingkungan tetapi kurang bisa menerapkan perilaku-perilaku yang seharusnya dilakukan dalam menjaga lingkungan untuk keberlanjutan usahatani paprika. Dengan menjaga lingkungan saat melaksanakan usahatani paprika, maka akan berdampak pada keberlanjutan agribisnis paprika. 
Tabel 3 Kinerja keberlanjutan dimensi lingkungan agribisnis paprika di Kabupaten Bandung Barat

\begin{tabular}{|c|c|c|}
\hline Indikator & Indeks Rata-rata & Kinerja \\
\hline \multicolumn{3}{|l|}{ 1. Kesadaran petani terhadap lingkungan } \\
\hline $\begin{array}{l}\text { Unsur lingkungan adalah faktor yang harus dipertimbangkan dalam } \\
\text { usahatani paprika }\end{array}$ & 3.48 & Baik \\
\hline $\begin{array}{l}\text { Usahatani paprika memiliki manfaat untuk memperbaiki dan } \\
\text { menjaga aspek lingkungan yang bermanfaat bagi generasi di masa } \\
\text { mendatang }\end{array}$ & 3.10 & Cukup \\
\hline $\begin{array}{l}\text { Limbah dari pembersihan akhir musim paprika dijadikan pupuk } \\
\text { organik }\end{array}$ & 2.71 & Cukup \\
\hline $\begin{array}{l}\text { Melakukan pemasangan sumur penyerapan air agar ketersediaan air } \\
\text { dapat terus terjaga }\end{array}$ & 2.37 & Tidak baik \\
\hline Kinerja kesadaran petani terhadap lingkungan & 2.92 & Cukup \\
\hline 2. Adaptasi dan mitigasi perubahan iklim & 2.95 & Cukup \\
\hline Penyesuaian jadwal tanam untuk mengantisipasi perubahan iklim & 2.79 & Cukup \\
\hline Penanganan darurat dilakukan ketika terjadi perubahan iklim & 3.06 & Cukup \\
\hline Penanganan dilakukan sebelum terjadi perubahan iklim & 3.03 & Cukup \\
\hline $\begin{array}{l}\text { Penutupan seluruh greenhouse dengan plastik UV karena hama } \\
\text { semakin tidak terbendung }\end{array}$ & 2.91 & Cukup \\
\hline Kinerja adaptasi dan mitigasi perubahan iklim & 2.95 & Cukup \\
\hline \multicolumn{3}{|l|}{ 3. Efisiensi penggunaan air } \\
\hline Penyiraman dilakukan secara manual sudah efisien & 3.24 & Cukup \\
\hline Penyiraman dilakukan dengan irigasi tetes lebih efisien & 3.30 & Cukup \\
\hline $\begin{array}{l}\text { Penggunaan media tanam yang tetap membuat penggunaan air } \\
\text { menjadi lebih efisien }\end{array}$ & 3.67 & Baik \\
\hline $\begin{array}{l}\text { Ketelitian buruh tani dalam penyiraman akan membuat penggunaan } \\
\text { air menjadi lebih efisien }\end{array}$ & 3.74 & Baik \\
\hline Efisiensi penggunaan air & 3.49 & Baik \\
\hline Total skor kinerja keberlanjutan dimensi lingkungan & 3.12 & Cukup \\
\hline
\end{tabular}

Kinerja mitigasi perubahan iklim memperoleh kategori cukup. Hal ini disebabkan karena kebanyakan petani paprika tidak melakukan adaptasi dan mitigasi perubahan iklim dengan alasan tanaman berada di dalam greenhouse maka pengaruh iklim tidak terlalu besar terhadap tanaman.

Kinerja efisiensi penggunaan air menunjukkan memperoleh kategori baik. Kinerja berkelanjutan ini diperoleh dari pemahaman yang baik dari petani bahwa penggunaan air pada proses budidaya paprika sangat penting, oleh sebab itu petani harus bisa seefisien mungkin dalam menggunakan air.Petani memahami betul penggunaan irigasi tetes menjadikan penggunaan air lebih efisien tetapi kebanyakan petani tidak memiliki modal untuk menggunakan teknik penyiraman tersebut, padahal dalam hidroponik seperti yang telah dibahas sebelumnya bahwa air merupakan faktor yang penting dalam proses budidayanya (Gashgari et al., 2018).

Kinerja Keberlanjutan Dimensi Teknologi. Kinerja keberlanjutan dimensi teknologi yang dibahas terdiri dari produktivitas, inovasi teknologi dan pengendalian risiko produksi. Secara umum total skor kinerja keberlanjutan dimensi teknologi berdasarkan perolehan indeks rata-rata pada agribisnis paprika di Kabupaten Bandung Barat memperoleh tingkatan kinerja cukup. (Tabel 4).

Produktivitas merupakan salah satu faktor penentu kinerja dari dimensi teknologi karena dengan penggunaan teknologi yang tepat maka akan menghasilkan produktivitas yang optimal. Kinerja produktivitas pada agribisnis paprika di Kabupaten Bandung Barat memperoleh tingkatan baik. Perolehan kinerja tersebut 
berhubungan dengan bagaimana cara petani dalam melakukan budidaya paprika dengan teknik atau teknologi yang tepat sehingga menghasilkan produktivitas yang optimal. Menurut (Faroka et al., (2011), teknologi yang menghasilkan peningkatan produktivitas membuat keberlanjutan teknologi tercapai sehingga kontribusi produktivitas tinggi terhadap keberlanjutan dimensi teknologi.

Tabel 4 Kinerja keberlanjutan dimensi teknologi agribisnis paprika di Kabupaten Bandung Barat

\begin{tabular}{|c|c|c|}
\hline Indikator & $\begin{array}{c}\text { Indeks Rata- } \\
\text { rata }\end{array}$ & Kinerja \\
\hline \multicolumn{3}{|l|}{ 1. Produktivitas } \\
\hline $\begin{array}{l}\text { Produktivitas paprika lebih tinggi jika ada keselarasan dari } \\
\text { penyediaan input hingga pemasaran. }\end{array}$ & 3.74 & Baik \\
\hline $\begin{array}{l}\text { Varietas benih dengan kualitas baik akan meningkatkan } \\
\text { produktivitas paprika }\end{array}$ & 3.71 & Baik \\
\hline $\begin{array}{l}\text { Penggunaan pestisida secara teratur dapat meningkatkan } \\
\text { produktivitas yang dihasilkan }\end{array}$ & 3.67 & Baik \\
\hline Pemberian pupuk sesuai anjuran meningkatkan produktivitas & 3.06 & Cukup \\
\hline Kinerja produktivitas & 3.54 & Baik \\
\hline \multicolumn{3}{|l|}{ 2. Inovasi Teknologi } \\
\hline Teknologi budidaya paprika tersedia dan mudah diakses & 1.91 & Tidak baik \\
\hline Selalu mengikuti perkembangan teknologi budidaya paprika & 1.88 & Tidak baik \\
\hline Melakukan ujicoba jika ada teknologi baru & 1.97 & Tidak baik \\
\hline Menerapkan teknologi yang baru dan sudah berkembang & 1.95 & Tidak baik \\
\hline Kinerja inovasi teknologi & 1.91 & Tidak baik \\
\hline \multicolumn{3}{|l|}{ 3. Pengendalian risiko produksi } \\
\hline Melakukan pola tanam mengurangi risiko produksi & 3.31 & Cukup \\
\hline Penggunaan benih unggul mengurangi risiko produksi & 3.76 & Baik \\
\hline Pemberian pestisida secara teratur mengurangi risiko produksi & 3.84 & Baik \\
\hline $\begin{array}{l}\text { Pemberian pupuk } \mathrm{AB} \text { mix secara teratur mengurangi risiko } \\
\text { produksi }\end{array}$ & 3.13 & Cukup \\
\hline Pengendalian risiko produksi & 3.51 & Baik \\
\hline Total skor kinerja keberlanjutan dimensi teknologi & 2.99 & Cukup \\
\hline
\end{tabular}

Kinerja keberlanjutan dimensi teknologi berkaitan dengan inovasi teknologi memperoleh kategori tidak baik. Perolehan kinerja tidak baik ini diakibatkan karena kurangnya inovasi teknologi yang tersedia. Menurut Asnawi (2014) inovasi teknologi dapat meningkatkan produktivitas dan pendapatan petani. Kenyataannya menurut Larsen et al., (2009), inovasi agribisnis pada negara berkembang biasanya berfokus pada inovasi pasar dan kelembagaan bukan pada inovasi teknologi.

Kinerja pengendalian risiko produksi pada agribisnis paprika di Kabupaten Bandung Barat memperoleh kategori baik. Petani paprika memahami beberapa hal yang dapat mengurangi risiko produksi seperti penentuan pola tanam, pemberian pestisida sesuai anjuran, pemberian nutrisi secara teratur dan penggunaan benih unggul. Risiko produksi biasanya terjadi karena adanya gangguan terhadap tanaman baik hama maupun penyakit.

Kinerja Keberlanjutan Dimensi Kelembagaan. Kinerja keberlanjutan dimensi kelembagaan yang dibahas terdiri daridukungan sosial budaya masyarakat dan dukungan dan peran pemerintah. Secara umum total skor kinerja keberlanjutan dimensi kelembagaan berdasarkan perolehan indeks rata-rata pada agribisnis paprika di Kabupaten Bandung Barat memperoleh tingkatan kinerja cukup (Tabel 5). 
Indikator yang memperoleh indeks rata-rata tertinggi yaitu usahatani dikelola kelompok dan usahatani membantu warga sekitar yang tidak memiliki pekerjaan. Agribisnis paprika di Kabupaten Bandung Barat didominasi oleh kelompok tani dalam arti kelompok tani memiliki kekuatan lebih dalam permodalan bahkan dalam penyediaan pasar. Sebagaimana hasil penelitian Santoso \& Purbayu Budi (2015) bahwa pembentukan kelompok tani dapat meningkatkan keberlanjutan suatu lembaga.

Tabel 5 Kinerja keberlanjutan dimensi kelembagaan agribisnis paprika di Kabupaten Bandung Barat

\begin{tabular}{|c|c|c|}
\hline Indikator & $\begin{array}{l}\text { Indeks Rata- } \\
\text { rata }\end{array}$ & Kinerja \\
\hline \multicolumn{3}{|l|}{ 1. Dukungan dsosial budaya masyarakat } \\
\hline $\begin{array}{l}\text { Mengikuti penyuluhan/pelatihan karena didorong warga } \\
\text { masyarakat }\end{array}$ & 2.46 & Cukup \\
\hline Usahatani paprika dikelola oleh kelompok/komunitas & 3.71 & Baik \\
\hline Mengusahakan paprika sudah menjadi budaya setempat & 3.67 & Baik \\
\hline $\begin{array}{l}\text { Melakukan usahatani paprika membantu warga sekitar yang tidak } \\
\text { memiliki pekerjaan tetap }\end{array}$ & 3.74 & Baik \\
\hline Kinerja dukungan sosial budaya masyarakat & 3.39 & Baik \\
\hline \multicolumn{3}{|l|}{ 2. Dukungan dan peran pemerintah } \\
\hline Pelatihan budidaya paprika selalu diadakan pemerintah & 2.76 & Cukup \\
\hline $\begin{array}{l}\text { Pemerintah rutin mengadakan program bantuan sarana dan } \\
\text { prasarana produksi }\end{array}$ & 2.73 & Cukup \\
\hline $\begin{array}{l}\text { Program pengenalan teknologi terbaru untuk paprika sering } \\
\text { dilakukan }\end{array}$ & 2.51 & Tidak baik \\
\hline Program studi banding ke negara lain sering dilakukan & 2.50 & Tidak baik \\
\hline Kinerja dukungan dan peran pemerintah & 2.63 & Cukup \\
\hline Total skor kinerja keberlanjutan dimensi kelembagaan & 3.01 & Cukup \\
\hline
\end{tabular}

Kinerja dimensi kelembagan berkaitan dengan dukungan dan peran pemeritah pada agribisnis paprika di Kabupaten Bandung Barat memperoleh kategori cukup. Perolehan tersebut karena kurangnya dukungan pemerintah terhadap komoditas paprika. Dukungan pemerintah memegang peran penting dalam meningkatkan keberlanjutan kelembagaan sebagaimana hasil penelitian Akbar \& Mohi, (2017), bahwa peran pemerintah dalam menunjang peningkatan pendapatan petani yang tergabung dalam suatu lembaga berpengaruh signifikan dan memberikan manfaat kepada petani tersebut.

\section{KESIMPULAN}

Secara umum keberlanjutan agribisnis paprika dilihat dari 5 dimensi termasuk kategori cukup, sedangkan dimensi yang mendapatkan nilai paling tinggi dari indeks rata-rata yaitu dimensi sosial dengan kategori cukup. Nilai indeks rata-rata terkecil diperoleh dimensi teknologi dengan kategori cukup. Hal tersebut mengindikasikan bahwa perlunya peningkatan dalam dimensi teknologi untuk meningkatkan kinerja keberlanjutan agribisnis paprika di Kabupaten Bandung Barat.

\section{DAFTAR PUSTAKA}

Akbar, M. F., \& Mohi, W. K. (2017). Peran Pemerintah Desa Dalam Menunjang Pendapatan Masyarakat Petani Jagung Di Desa Dulohupa Kecamatan Boliyohuto Kabupaten Gorontalo. CosmoGov, 3(2), 171. https://doi.org/10.24198/cosmogov.v3i2.14727

Al-Hafiz MP. 2016. Ingin Investasi Kebun Paprika. [diunduh 30 Agustus 2019]. Tersedia pada: https://marketeers.com/ingin-investasi-di-kebun-paprika/ 
Anoviansyah, Y., Sepriani, Y., \& Sarkum, S. (2018). Pengaruh Permintaan Cabai Merah Terhadap Pendapatan Kelompok Tani Cabai Di Kabupaten Labuhanbatu. Agrifo, 3(2), 1-4.

Asnawi, R. (2014). Peningkatan Produktivitas dan Pendapatan Petani Melalui Penerapan Model Pengelolaan Tanaman Terpadu Padi Sawah di Kabupaten Pesawaran, Lampung Increasing of Productivity and Farmers Income Through Application of Integrated Crops Management Model on Paddy. Jurnal Penelitian Pertanian Terapan, 14(1), 44-52.

[bps]. Badan Pusat Statistik. 2019. Produksi Paprika Menurut Provinsi Tahun 2018. Indonesia: bps.

Daniel, M. (2004). Pengantar Ekonomi Pertanian. PT Bumi Aksara.

[ditjen hortikultura]. Direktorat Jenderal Hortikultura. 2006. Standar Prosedur Operasional Tanaman dalam Greenhouse. Indonesia: ditjen hortikultura.

Faroka, F. R., Seminar, K. B., \& Muljono, P. (2011). Pengaruh Adopsi Teknologi PHSL (Pemupukan Hara Spesifik Lokasi) Berbasis Pertanian Presisi terhadap Pendapatan Petani Padi di Desa Jembungan, Kabupaten Boyolali, Jawa Tengah. Jurnal Komunikasi Pembangunan, 1 (1).

Gashgari, R., Alharbi, K., Mughrbil, K., Jan, A., \& Glolam, A. (2018). Comparison between Growing Plants in Hydroponic System and Soil Based System. Proceedings of the 4th World Congress on Mechanical, Chemical, and Material Engineering, 1-7. https://doi.org/10.11159/icmie18.131

Guadagnoli, E. dan Velicer, W.F. 1988. "Relation of a sample size to the stability of component patterns". Psychological Bulletin. 103(2): 265-275.

Gunadi, N., Moekasan, T. K., \& Subhan, -. (2007). Identifikasi Potensi Dan Kendala Produksi Paprika Di Rumah Plastik. Jurnal Hortikultura, 17(1), 88-98. https://doi.org/10.21082/jhort.v17n1.2007.p

Hosseini, S. J. F., Mohammadi, F., \& Mirdamadi, S. M. (2011). Factors influencing the economic aspects of sustainable agriculture in Iran. World Applied Sciences Journal, 13(2), 287-294. https://doi.org/10.5897/AJAR10.954

[kementan]. Kementerian Pertanian Republik Indonesia. 2015. Data Produksi Sub Sektor Hortikultura Komoditas Paprika Tingkat Nasional. [diunduh 8 Mei 2019]. Tersedia pada: https://aplikasi.pertanian.go.id/bdsp/newdata.asp.

Larsen, Ronald, \& Florian. (2009). Agribusiness and Innovation Systems in Africa. Washington: The World Bank.

Munashinge. (1993). Environmental Economics and Sustainable Development.Environmental Departemen of The World Bank. Washington: The World Bank.

Novita, E., I.B.Suryaningrat, Andriyani, I., \& Widyotomo, S. (2012). Analisis Keberlanjutan Kawasan Usaha Perkebunan Kopi (KUPK) Rakyat Di Desa Sidomulyo Kabupaten Jember. Jurnal Agritech, 32(2).

Paramitha, N. A., \& Sulomo. (2018). Posisi Tawar Petani dalam Transaksi Ekonomi Pertanian. Jurnal Analisa Sosiologi, Vol. 7(No. 1), 70-84.

Ristianingrum, A., Chozin, M. A., Machfud, M., Sugiyanta, S., \& Mulatsih, S. (2016). Optimalisasi KeberlanjutanPengembangan Usaha Padi Organik Di Kabupaten Cianjur, Jawa Barat. Jurnal Manajemen Dan Agribisnis, 13(1), 37-49. https://doi.org/10.17358/jma.13.1.37

Santoso, Purbayu Budi, D. (2015). Strategy for Strengthening Farmer Groups by Institutional Strengthening Strategi Penguatan Kelompok Tani dengan Penguatan Kelembagaan. Jurnal Ekonomi Pembangunan, 16(1), 33-45.

Simamora, B. (2005). Analisis Multivariat Pemasaran. Jakarta: PT Gramedia Pustaka Utama. 